\title{
ICTS - NEW ORGANIZATIONAL FORM LINKAGE IN THE AUSTRALIAN CONTEXT: THEORETICAL MODEL AND RESEARCH INSTRUMENT
}

\author{
Ahmad Abareshi \\ Bill Martin \\ Alemayehu Molla \\ RMIT University, Melbourne, Australia
}

\begin{abstract}
Since the publication of the seminal article 'Management in the 1980s' (Leavitt and Whisler, 1958), the relationship between Information and Communications Technology (ICT) and organizations has been one of the most challenging issues for management scholars and researchers. Despite a long tradition of research that has been looking into the relationship between ICTs and organizations, the findings remain inconclusive. In particular, the specific mechanisms by which new information technologies affect and are affected by organizational forms have not been described in any systematic manner. This paper aims to make a contribution to address the above gap in research by developing an instrument and theoretical model that relates ICT and the attributes of new organizational forms (NOFs). Likert-type scale items were used for all scale items. Of the 3770 emails sent to top Australian managers, 312 were completed and returned. An Exploratory Factor Analysis was used to identify the underlying constructs in this research. The research findings provide an instrument whose properties were validated and ready to use in future research.
\end{abstract}

Keywords: IT Strategic Alignment, new organizational forms, information and communication technologies, Australia

Manuscript first received/Recebido em 14/05/2011 Manuscript accepted/Aprovado em: 22/09/2011

Address for correspondence / Endereço para correspondência

Ahmad Abareshi, PhD. Lecturer in the School of Business IT and Logistics, RMIT University, Australia. He holds a Bachelor degree in management, MBA in Operations Research, and a PhD in Information Technology RMIT University School of Business IT and Logistics, RMIT University, Melbourne, .Bld 108 Level 16 Room 65 Bourke Street, Melbourne 3001, Australia. Phone: +61 399255918 Fax: +61 3 99255850 Email: ahmad.abareshi@rmit.edu.au

Bill Martin, PhD. Research director in the School of Business IT and PhD Supervisor, Research and consultant in the area of business models for digital models for digital publishing. School of Business IT, RMIT University, Melbourne, Australia. Phone 61399255843 Email: bill.martin@rmit.edu.au

Alemayehu Molla, Associate Professor, School of Business IT \& Logistics, RMIT University. He holds a Bachelor degree in management, a Master degree in information science, and a PhD in information systems. School of Business IT and Logistics, RMIT University, Melbourne, Bld 108 Level 17 Room 54 Bourke Street, Melbourne 3001, Australia. Phone: +61 399255803 Fax: +61 399255850 Email: alemayehu.molla@rmit.edu.au 


\section{INTRODUCTION}

Organizational form refers to the combination of strategy, structure, internal control, and coordination systems that provides an organization with its operating logic, resource allocation rules, and corporate governance mechanism (Creed and Miles, 1996). Since the evolution of conventional organizational forms such as hierarchical and bureaucratic, they have been continuously transforming into newer forms. New organizational forms (NOFs) have acquired a variety of labels including fluid form (Schreyögg and Sydow, 2010) network organization (Ghoshal et al., 1999; Maguire and Hardy, 2006), virtual organization (Davidow and Malone, 1992). Previous research has therefore focused on identifying the contexts, processes and variables that are associated with the emergence of these organisational forms. In terms of context, Beugre et al.(2006: 52) believes that the volatility of the external environment influences how organizations restructure themselves to cope with changes or to anticipate them. More recently, contingency approach (soft determinism) proposes that a set of factors have determined new forms of organizations. Globalization, deregulation, convergence of industries and rapid technological advancements, particularly in Information Technology (IT) and telecommunication are the contexts through which NOFs are emerging (Fulk and Desanctis, 1999). In terms of process, the progression toward new organizational forms has been gradual in most firms, dramatic in some, and non existent in others. A number of variables have also been associated both with the shape of and the underlying process that have resulted in NOFs. For instance, Fulk and Desanctis(1999: 5) showed how advances in IT could influence the socioeconomic systems and facilitate the evolution of NOFs. Developing a process-oriented model to assess the impacts of IT on critical business activities, Tallon et al. (2000: 145) propose strategic intent for IT and management practices as two variables that influence the organization.

An important new stream of thought stressing the importance of organizational fluidity has emerged in recent years. It represents a reaction to the increasing complexity and environmental turbulence that organizations have to master (Schreyögg and Sydow 2010).

\section{Organization Science}

This paper falls in the tradition of the research that has been looking into the variables that contribute to NOFs. Since the publication of the seminal article 'Management in the 1980s' (Leavitt and Whisler, 1958), the relationship between Information and Communications Technology (ICT) and organizations has been one of the most challenging issues for management scholars and researchers. What makes the ICT- organization relationship so thought-provoking is that not only does it touch the complex combinations of knowledge and the ICT synergies, but also its implications on a range of variables including cost, quality, accuracy, risk, efficiency and productivity (Sauer and Willcocks, 2004). Most, if not all (for example see: Winter and Taylor, 1999) of the previous research argued for a positive link between changes in ICTs and changes in some individual dimensions of the organization. This includes the effect of ICTs on firm's strategy, organization structure, internal control and operating systems, jobs and skills and behaviour, values and norms (Garicano, 2000; Panayides, 2004; White et al., 2005; Rajan and Wulf, 2006). Generically, ICTs are also associated with 
the emergence of new forms of organisations that operate a digital business, in the digital space and market with digital products and services (Apigian et al., 2006).

Despite a long tradition of research that has been looking into the relationship between ICTs and organizations, the findings remain inconclusive. In particular, the specific mechanisms by which new electronic technologies affect and are affected by organizational form have not been described in any systematic manner (Henderson and Venkatraman, 1999). In addition, there is limited research that has looked into the shape and form of the organisation that has been formed as a result of many years of ICTs assimilation. Further, although the impact of ICT at a very generic level is known, there is much less research that relates the specific attributes of ICTs (upstream factors) to attributes of NOFs (downstream factors) that emerge as a result impacts of ICTs. This paper aims to make a contribution to address the above gap in research. Hence, the purposes of the study are (1) to identify the features of new organisational forms (2) to develop an underlying model that relates these features to attributes of ICT and (3) to develop and test an instrument that aids in operationalising the model and (4) to discuss the theoretical and practical utility of the model and instrument.

\section{CONCEPTUAL FRAMEWORK}

Previous research on the effects of ICTs on the various dimensions of an organization has covered a number of variables. While some focus on the effect of ICTs on the organization size, scope and product, others specifically look at the effect of ICTs on vertical and horizontal control mechanisms. Following the advent of the Internet, the effect of ICTs on the quality of an organization's connection has received some research attention. Table 1 summarizes a sample selection of this literature.

Traditionally, organizational forms have been mainly designed for coordination and control purposes in the presence of time and distance barriers. According to Dutton (1999) technological innovations have led to changes in organizational forms offering new capabilities for overcoming such constraints. For example, telephone, telegraph, and mail systems have enabled organizations to have better organizational and interorganizational communication systems. Also, new ICTs have provided modern capabilities influencing organizational processes (Huber, 1993).

The combination of hardware, applications, infrastructure forms the capabilities of ICTs. As each of these dimensions develops, the concept, design and capabilities of ICTs would dramatically change. ICT resources cover a wide range of services such as e-mail, voice mail, teleconferencing, videoconferences, desktop, video- conferencing, computer aided design (CAD), discussion lists, information databases, groupware, intranet, e-procurement, e-logistics, e-government. A number of researchers have focused on the impact of these capabilities on organizational dimensions in general and on dimensions of NOFs in particular. For instance Marschak (2004: 473) believes that these capabilities have overcome the traditional communication difficulties and affected the role of middle managers and organizational hierarchy. In another study Panayides (2004: 35) pointed out how advanced ICT capabilities could decrease the size of the organization. Therefore, what is clearly deducted from this perspective is the influencing power of ICT infrastructures and capabilities on organizational dimensions. 
Table 1. ICT- Organization Literature

\begin{tabular}{|c|c|c|c|}
\hline Dimension & Author & Focus & Findings \\
\hline \multirow{7}{*}{$\begin{array}{l}\text { Vertical } \\
\text { Control }\end{array}$} & (Finnegan and & Role of IT in & IT facilitates \\
\hline & Longaigh, 2002) & $\begin{array}{l}\text { organizational control } \\
\text { and coordination }\end{array}$ & centralization of control \\
\hline & (Holland and Geoffrey & Mixed mode network & IT facilitates the \\
\hline & Lockett, 1997) & structures & $\begin{array}{l}\text { development of mixed } \\
\text { mode network structures. }\end{array}$ \\
\hline & (Argyres, 1999) & $\begin{array}{l}\text { IT impact on } \\
\text { coordination }\end{array}$ & $\begin{array}{l}\text { IT can facilitate } \\
\text { coordination within and } \\
\text { between organizations. }\end{array}$ \\
\hline & (Mukherji, 2002) & IT impacts on structure & $\begin{array}{l}\text { A natural compatibility } \\
\text { between IT and }\end{array}$ \\
\hline & (Marschak, 2004) & $\begin{array}{l}\text { IT and degree of } \\
\text { decentralization. }\end{array}$ & $\begin{array}{l}\text { Improved IT lowers } \\
\text { decentralization penalty. }\end{array}$ \\
\hline \multirow[t]{4}{*}{$\begin{array}{l}\text { Horizontal } \\
\text { Coordination }\end{array}$} & (Baker, 2002) & $\begin{array}{l}\text { The effect of IT on the } \\
\text { quality of decision } \\
\text { making. }\end{array}$ & $\begin{array}{l}\text { Significant improvement } \\
\text { in the quality of teams' } \\
\text { strategic decisions. }\end{array}$ \\
\hline & (Finnegan and & Role of IT in & IT facilitates \\
\hline & Longaigh, 2002) & $\begin{array}{l}\text { organizational control } \\
\text { and coordination }\end{array}$ & $\begin{array}{l}\text { depersonalization of } \\
\text { coordination mechanisms. }\end{array}$ \\
\hline & (Symon, 2000) & $\begin{array}{l}\text { Assessment of new } \\
\text { ways of organizing } \\
\text { and new technologies. }\end{array}$ & $\begin{array}{l}\text { Ambiguity on the ability } \\
\text { of IT to support the new } \\
\text { ways of organizing. }\end{array}$ \\
\hline \multirow[t]{2}{*}{$\begin{array}{l}\text { Type of } \\
\text { Connection }\end{array}$} & (Chae et al., 2005) & $\begin{array}{l}\text { IT and supply chain } \\
\text { collaboration }\end{array}$ & $\begin{array}{l}\text { The effect of IT on supply } \\
\text { chain collaboration is } \\
\text { determined by the } \\
\text { interplay between IT and } \\
\text { existing relationships } \\
\text { between partners. }\end{array}$ \\
\hline & (White et al., 2005) & $\begin{array}{l}\text { IT impact on supply } \\
\text { chain management. }\end{array}$ & $\begin{array}{l}\text { Increase in levels of } \\
\text { integration between } \\
\text { partners' information } \\
\text { systems, and agility in the } \\
\text { supply chain. }\end{array}$ \\
\hline
\end{tabular}

As ICT needs a huge amount of organizational capital, there has always been a concern about the effectiveness of ICT investment. Successful ICT investment can not be achieved without commitment to change in general and IT project in particular. Since top management has a broader view over different internal and external organizational issues, their role in taking most advantages of ICT capabilities is irrefutable. In their process-oriented model, Tallon et al. (2000: 145) incorporated management practices as the key determinant of IT capabilities. They showed how top executives with more focused goals for IT could bring more IT capabilities into action. Top management make a variety of organization decision making, including planning, design, resource 
allocation, and implementation activities (Thong et al., 1996). This in turn would somehow affect ICT structure and capabilities. In another study, Luftman and Kempaiah(2008: 99) identified senior executive support for IT as one of the key factors in a successful IT investment.

\section{Control}

The nature of control is one key attribute of NOF. It is related to the extent of centralization or decentralization of decision making. Centralization refers to the extent to which decision making authority is dispersed or centralized in an organisation (Richardson et al., 2002). Traditionally, external and internal information are the domain of top management; however, owing to increased global competition in recent decades, many organisations have moved decision making to lower levels of their organisation to take advantage of specialized staff (Fulk and Desanctis, 1999). There are no simple answers to the forms of control employed in NOFs. Kotorov(2001: 55) showed how spatial decentralization is prevalent in virtual organization. Using the organization of the research and development (R\&D) function Hill, Martin et al. (2000: 563) supported the relevance of theories of increased decentralization in post bureaucratic forms. Kartseva, Gordijn et al. (2005: 57) argued that an important aspect of network organizations is that controls are typically not imposed on the network by a central authority but are negotiated by the network partners.

\section{Coordination}

Surviving in the current uncertain environment requires a high level of coordination among different parts of the organisation. In terms of concurrent engineering, it is worth noting that instead of employing sequential processing, NOFs have been employing parallel and concurrent processing. As zero inventory can reduce the total of cost of production, Piore (1994) argued that the elimination of inventory would lead to greater interdependency among organisational units and to greater lateral communication and less hierarchy. The last area of coordination focuses on the attributes of virtual organisations. Among the different dimensions of virtual organisations, those of the electronic rather than the material nature of data, or being structureless and having ambiguous external boundaries are of high importance (Nohria and Berkley, 1994). Therefore, "A coordination-intense structure" is another attribute of NOFs.

\section{Communication}

More importantly, surviving in new volatile environments requires organisations to continuously pursue organisational innovation. New organizational forms depend on communication for dealing with ever more complex interorganizational relationships. Communication plays an important role in facilitating the innovation processes and is 
considered as the core feature in NOFs. Virtual organizations, as a new form of organization, depend on the communication among organisational and geographically dispersed employees work in virtual team settings (Workman, 2007). Heckscher (1994: 14) argues that in NOFs, relationships depend on trust, a high degree of shared vision, and broad communication about the corporate strategy. Therefore, communication technologies can play an important role to facilitate the information flow among people, many of whom may never have met each other. Consequently 'weak ties' among organisational staff would be supported. In other words, in such forms coordination is accomplished by individuals and teams with cross-functional, computer -mediated jobs. Free communication flows and shared access to information and knowledge are regarded as essential in NOFs (Cairncross, 2001). Thus, contrary to classic theories of organization, information should be available to all members of the organization, irrespective of specialization and/or hierarchical position (Levine et al., 1999). In NOFs the demands for the rapid action have increased, so it is increasingly necessary to have people at all levels who are powered to act based on their first-hand knowledge of the issue and their capacities for exercising judgment and initiative. Therefore, the information should be accessible to all people. In NOFs there should be sufficient autonomy and clear organizational vision must be articulated and committed to (Chowdhury, 2003).

The above review indicates that by looking at the nature of control, coordination and communication, it is possible to identify if an organisation demonstrates an NOF feature. Therefore, based on the above discussion on some dimensions of NOFs for the purpose of this study, we define NOFs as an organizational form which is decentralized form with horizontal coordination and high level of communication. Therefore, we posited that a multi-perspective of technological and managerial issues can provide meaningful indicators of the ICTs-NOFs linkage. We use the concept of ICT Assets to capture all the ICT capabilities and functionalities which affect the organizational dimensions and ICT Management to represent management of ICT in organizations. NOF represents some of the features and attributes of new organizations. We identified three constructs- ICT Assets, ICT Management, and NOFs as shown in Figure 1.

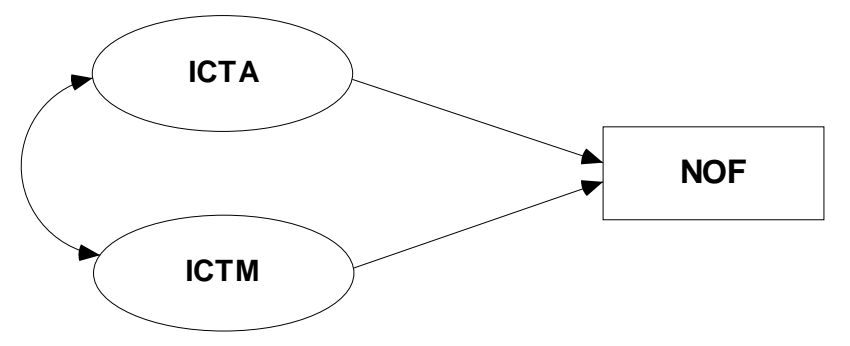

Figure 1. The Initial Research Model

\section{RESEARCH METHODS}

This study is deductive in nature which is followed by gathering data and using some descriptive statistics to conceptualize the research theoretical model being proposed. The main research objective is to develop a theoretical model explaining how and to what extent ICT can contribute to the evolution of new organizational forms. The survey strategy was employed because it enables researchers to work with a large amount of data in a highly economical way. Prior to designing the research instrument, 
the existing instruments were considered. STROBE (Venkatraman, 1989) and STROPIS (Chan et al., 1997) instruments were chosen and revised. In designing final instrument the instrument development procedure suggested by Churchill (1979: 64) was followed that involved specifying domain of constructs, generating sample of items, collecting data, and assessing the validity and reliability of the measure.

\subsection{Domain of constructs}

Clearly research constructs are needed to investigate any linkage between ICTs and NOFs, but there is the immediate issue of which are likely to be the most relevant. It is difficult to conceptualize all dimensions of NOFs and to determine all variables that could affect the evolution of NOFs. Therefore, only those variables are considered, to some extent, related to information and communication technologies. Organizations attempt to use systems that support their strategic orientations. However, for different reasons, such as resource constrains or internal stability, some organizations would be more successful at developing appropriate systems than others. What is ignored in ICTs literature is the synergetic effects of ICTs where combined with other organizational potentials such as business strategy (Byrd et al., 2006). Hence, the alignment between IT and business strategy is of high importance. Alignment involves "applying information technology (IT) in an appropriate and timely way and in harmony with business strategies, goals, and needs" (Luftman and Brier, 1999). Although several factors are thought to contribute to the evolution of NOFs, a major force lies in the capabilities provided by ICTs. Over recent years, several different arguments have been offered to highlight the potential of ICTs to enable and shape an organizational form (Rajan and Wulf, 2006).On the basis of the literature along with conducting a focus group discussion that consists of three IT managers and two academics, we identified one variable related to the ICT assets construct, that is ICT Dynamics and two variables related to ICT management, that is, IT strategic alignment and management support. A number of the characteristics of NOFs were identified. In the following section, we discuss each variable briefly.

- $\quad$ IT strategic alignment (ITSA)

- $\quad$ ICT capabilities and potentials (ICTC)

- $\quad$ Management Support (MS)

- $\quad$ Characteristics of NOFs (NOFC)

IT Strategic Alignment (ITSA) refers to the extent to which the IT mission, objectives, and plans support and are supported by the organization mission, objectives, and plans (Hirschheim and Sabherwal, 2001). While there is widespread consensus that organizational and IT strategies should be linked (Niederman and Brancheu, 1991) such an alignment has not been easily and clearly understood by practicing managers (Hirschheim and Sabherwal, 2001; Chan, 2002). Among different approaches to investigation of the mutual interaction between ICTs and organisation, that of the IT Strategic Alignment model, seems most likely to precisely describe this linkage. A successful strategic alignment is unlikely without advanced communication systems as such systems enable organisations to share the required real-time information between each other. The interlinking of organisational relationships across a wide range of industries, form banking to insurance, is resulting in complex alliance webs in which 
one organisation can serve simultaneously not only as a supplier, but also as a competitor, customer, and consultant. The result is a circular value chain and new forms of interdependence (Fulk and Desanctis 1995). Based on the need to achieve alignment across business and IT areas, Henderson and Venkatraman(1999: 472) proposed an IT strategic alignment model. In their model business strategy refers to realized business strategy and focuses on the "resource deployment patterns" that organizations employ to achieve their objectives. It is defined at the business unit level. It contains dimensions including: Aggressiveness, Analysis, Defensiveness, Innovativeness, and Proactiveness. There are five dimensions parallel to business strategy to measure IT strategy. In this regard, it is focused on the capabilities provided by IT to support different business strategies. Among different available models to investigate IT strategic alignment, the one proposed by Henderson and Venkatraman was employed. The Strategic Alignment Model provides a clear and concise basis to evaluate the strategic fit and functional integration of an organisation's business and IT strategies on its structure. Thus, it is argued that there is an underlying relationship between the strategy (whether business or IT strategy) an organisation pursues and the resulting structure. Two previously validated scales were used to measure the alignment between business strategy and IT strategy. These scales are STROBE (Henderson and Venkatraman, 1999) and STROEPIS (Chan et al., 1997). Among two methods to calculate the alignment, the moderation model was employed as it consistently outperforms the matching models. While ICTs are different, and thus create different challenges, over time organisations have developed unique sets of IT capabilities. Owing to these differences, some organisations have been able to develop more successful IT infrastructures than their competitors (Wade and Hulland 2004). ICT capabilities that have received research attention include technical skills, IT management skills, and relationship assets (Piccoli and Ives 2005).

ICT capabilities and potentials (ICTC) refers to ICT capabilities and functionalities which can influence the organizational dimensions including the amount of investment in ICT, the variety in ICT usage, and the sourcing structure for ICT. Schilling and Steensma (2001: 1149) provided a causal model indicating how technological changes could influence the evolution of modular organizational forms in the US manufacturing sector. Also Stiroh (2002: 1559) provided some evidence of how information technology would influence the firms' boundaries and could enhance communication and coordination both between the firm and its partners, and within the firm itself. The technical IT infrastructure encompasses the physical IT and communications resources of an organization, along with the shared services and business applications. It encompasses an organization's network, storage, data, and application assets as well as the network critical physical infrastructures (Byrd and Turner, 2000). ICT resources cover a wide range of services such as e-mail, voice mail, teleconferencing, videoconferences, desktop, video-conferencing, computer aided design (CAD), discussion lists, information databases, groupware, intranet, eprocurement, e-logistics, and e-government. A number of researchers have focused on the impact of these capabilities on organisational dimensions in general and on dimensions of NOFs in particular. For instance, Marschak (2004: 473) believes that these capabilities have overcome the traditional communication difficulties and affected the role of middle managers and organisational hierarchy. In another study, Panayides (2004: 35) pointed out how advanced ICT capabilities could decrease the size of an organisation. Put differently, several factors are thought to contribute to the evolution of 
NOFs, but the capabilities provided by ICTs are a major influence. Over recent years, several different arguments have been offered to highlight the potential of ICTs to enable and shape organisational forms (Rajan and Wulf, 2006). The combination of hardware, applications, and infrastructure shapes the capabilities of ICT. As each of these dimensions develops, the concept, design and capabilities of ICT would dramatically change.

ICT has decreased the size of middle management in organisations, especially with the advent of centralized decision making authority (McNulty and Ferlie, 2004). Decreasing the role middle management played in organisations would lead to a networked, flat organisational hierarchy. Miles and Snow (2005: 162) claim that the new 'spherical' organisational form is based on "leadership as a shared responsibility among colleagues, not as superior-subordinate relationship". This outcome is supported by shifting the role of ICT from a back office function to a more influential one. IT is precisely due to this powerful capacity of ICTs, that many human contributions have been substituted by ICTs (Fulk and Desanctis, 1999). ICTs are seen to provide organisational employees with global data that will permit them to make local decisions consistent with overall organisational goals. As the flexibility of ICT enables it to handle a huge amount of processing jobs, these technologies can be configured to substitute for some traditional managerial roles.

Management Support (MS) refers to the extent of management support for ICT promotion in organizations.

As ICT requires commitment of a huge amount of organisational capital, there has always been a concern about the effectiveness of ICT investment. Successful ICT investment can not be achieved without commitment to changes in organisation. Since top management has a broader view over the different internal and external organisational issues, their role in making the most advantages of ICT capabilities is indisputable. In their process-oriented model, Tallon et al. (2000: 145) incorporated management practices as the key determinant of IT capabilities. They showed how top executives with more focused goals for IT could bring more IT capabilities into play. This in turn will affect ICT structure and capabilities. Luftman(1999: 109) identified senior executive support for IT as one of the key factors in a successful instance of IT investment. Management support was operationalized by assessing top management attitudes regarding ICTs capabilities and the extent of top management support for technological innovation (Luftman and Kempaiah, 2008). Brynjolfsson and Hitt(2002: 23) emphasized on the importance of management on the success of ICT investments. They believed that any relationship between ICTs and organizational change is due to the temperament of management rather than their economic capabilities.

Characteristics of NOFs refer to the combination of strategy, structure, internal control, and coordination systems that provides an organization with its operating logic, resource allocation rules, and corporate governance mechanisms. Table 2 summarizes the definitions of variables for each construct used in the proposed model.

\subsection{Instrument Development}

A pilot study was conducted with industry practitioners to examine the external validity of the constructs. The purpose of the pilot study was to ensure the vigorousness 
of the model and the initial instrument. The pilot study consisted of five people, including two academics, one from a government organization, and two persons from private sector. They were provided with the initial research model and the proposed variables to establish the basic unassailability of model. No modification was made at the end of this stage. For the research constructs, we then developed the questionnaire items based on the literature as well as on comments obtained from the pilot study. The survey questionnaire was revised by members of the member of pilot study. In formulating the initial instrument for determining the level of IT-Strategic Alignment, Venkatraman's STROBE (Strategic Orientation of Business Enterprises) instrument (Venkatraman 1989) and Chan's STROPIS (STRategic Orientation of the Existing Portfolio of Information Systems) instrument (Chan, Huff et al. 1997) were used and revised. Venkatraman's STROBE instrument seeks to develop valid measurements of key dimensions of the business strategy construct.

It focuses on the "resource deployment patterns" that organizations employ to achieve their objectives. Using eight quantified characteristics of business strategy Venkatraman proposed a STROBE scale. These characteristics are: aggressiveness, analysis, internal defensiveness, external defensiveness, futurity, proactiveness, riskiness, and innovativeness. Chan's STROPIS instrument operates in parallel to STROBE, i.e., for each individual STROBE variable, there is a parallel variable in STROPIS. For instance, aggressiveness is one of the dimensions used to measure business strategy. The parallel STROPIS variable would be: IT supports for aggressiveness. Table 3 presents the reliability of six constructs in STROBE and STROPIS instruments. For parsimonious purposes, we combined the Riskiness and Futurity dimensions and created a revised dimension named Innovativeness. The items designed for the new dimension covered both futurity and riskiness. The items for the rest of the dimensions were employed for STROBE and STROPIS. 
ICTs -New Organizational Form linkage in the Australian Context: Theoretical Model and Research Instrument

\begin{tabular}{|c|c|c|c|}
\hline Variables & \multirow[t]{2}{*}{ Description } & \multirow{2}{*}{$\begin{array}{l}\text { Number } \\
\text { of Items }\end{array}$} & \multirow[t]{2}{*}{ References } \\
\hline $\begin{array}{l}\text { Business } \\
\text { Strategy }\end{array}$ & & & \\
\hline Aggressiveness & $\begin{array}{l}\text { The ways in which businesses implement } \\
\text { resource allocation for pursuing aggressive } \\
\text { strategies. }\end{array}$ & 5 & \multirow{6}{*}{$\begin{array}{l}\text { (Venkatraman, } \\
\text { 1985; Chan et al., } \\
\text { 1997; Hussin et al., } \\
\text { 2002; Pierce, 2002; } \\
\text { Chan et al., 2006) }\end{array}$} \\
\hline Analysis & $\begin{array}{l}\text { Tendency to search and develop the best } \\
\text { possible alternatives in organizational } \\
\text { decision-making }\end{array}$ & 2 & \\
\hline \multirow[t]{2}{*}{ Defensive } & $\begin{array}{l}\text { Maintaining the current position and } \\
\text { defending the right to play in the market, } \\
\text { say by employing cost reduction strategies. }\end{array}$ & 4 & \\
\hline & $\begin{array}{l}\text { The development and early adoption of } \\
\text { innovations. }\end{array}$ & 2 & \\
\hline Innovative & $\begin{array}{l}\text { Active participation in emerging industries } \\
\text { and a continuous search for market } \\
\text { opportunities to anticipate and predict the } \\
\text { future in both business and technology } \\
\text { markets. }\end{array}$ & 5 & \\
\hline \multirow{2}{*}{\multicolumn{4}{|c|}{$\begin{array}{l}\text { Proactiveness } \\
\text { IT Strategy }\end{array}$}} \\
\hline & & & \\
\hline $\begin{array}{l}\text { IT for } \\
\text { Aggressiveness }\end{array}$ & $\begin{array}{l}\text { The capabilities provided by IT to support } \\
\text { aggressiveness strategy. }\end{array}$ & 4 & \multirow{5}{*}{$\begin{array}{l}\text { Chan et al., 1997; } \\
\text { Pierce, 2002; } \\
\text { Kearns and } \\
\text { Lederer, 2003; } \\
\text { Kearns and } \\
\text { Sabherwal, 2006) }\end{array}$} \\
\hline IT for analysis & $\begin{array}{l}\text { The capabilities provided by IT to support } \\
\text { analysis strategy }\end{array}$ & 3 & \\
\hline $\begin{array}{l}\text { IT for } \\
\text { defensiveness }\end{array}$ & $\begin{array}{l}\text { The capabilities provided by IT to support } \\
\text { defensive strategy }\end{array}$ & 3 & \\
\hline $\begin{array}{l}\text { IT for } \\
\text { innovative }\end{array}$ & $\begin{array}{l}\text { The capabilities provided by IT to support } \\
\text { innovative strategy }\end{array}$ & 3 & \\
\hline $\begin{array}{l}\text { IT for } \\
\text { proactiveness }\end{array}$ & $\begin{array}{l}\text { The capabilities provided by IT to support } \\
\text { proactiveness strategy }\end{array}$ & 4 & \\
\hline ICT Dynamics & $\begin{array}{l}\text { Refers to the varieties of IT usages, } \\
\text { different course of action organization uses } \\
\text { in meeting IT needs, and to the division of } \\
\text { labour and responsibility for managing IT } \\
\text { activities in organizations }\end{array}$ & 3 & $\begin{array}{l}\text { (Fulk and } \\
\text { Desanctis, 1995; } \\
\text { Tallon et al., 2000; } \\
\text { (NOIE), 2005) }\end{array}$ \\
\hline $\begin{array}{l}\text { Management } \\
\text { Support }\end{array}$ & $\begin{array}{l}\text { Refers to the extent of management support } \\
\text { on ICT promotion in organization. }\end{array}$ & 5 & $\begin{array}{l}\text { (Thong et al., 1996; } \\
\text { Luftman, 1998; } \\
\text { Tallon et al., 2000; } \\
\text { (NOIE), 2005) }\end{array}$ \\
\hline NOFs & $\begin{array}{l}\text { It covers the areas of organization structure, } \\
\text { internal control, resource allocation rules, } \\
\text { corporate governance mechanism, division } \\
\text { of labour, coordination systems, } \\
\text { communication, and centralization of } \\
\text { decision-making. }\end{array}$ & 20 & $\begin{array}{c}\text { (Heydebrand, 1989; } \\
\text { Nohria and } \\
\text { Berkley, 1994; } \\
\text { Bowman et al., } \\
\text { 1999; Fulk and } \\
\text { Desanctis, 1999; } \\
\text { Moller and Rajala, } \\
\text { 1999; Dewett and } \\
\text { Jones, 2001) }\end{array}$ \\
\hline
\end{tabular}

Table 2 Research Variables 


\subsection{Panel of Expert}

To pre-test the relevance and reliability of the instrument, we conducted a survey with a panel of experts. The initial questionnaire was sent to 307 internationally recognized academics in the field of ICT-organization and practitioners who were randomly selected from a rental database. Although some of the items we have used are pooled from previously validated instruments, in order to establish the current relevance of these items, we have surveyed a panel of experts. The participants were asked to judge the degree of relevance of individual items using a five point Likert scale ranging from not relevant (1) to extremely relevant (5). Of 307 questionnaires sent to the participants, we received 34 responses $(11.1 \%$ response rate). The response rate was reasonable for the purpose of this purpose (Wang and Tang, 2001). Intra-class (Interrater) reliability, which is usually reported as a correlation coefficient, provides a measure of how well two or more raters agree in their assessment of a variable (Litwin, 1995). At $p=0.01$ all correlation coefficients between raters were significant indicating high reliability of the judgements. The Mean Relevance Score (MRS) was employed to determine those items that should be dropped from the initial instrument (Molla and Licker, 2005). MRS was more than average, 2.5, for all items so no items were removed from the final instrument. Then the internal consistency of the instrument was assessed using Cronbach's alpha. Cronbach's alpha values ranged from 0.71 for ICT Dynamics to 0.82 for IT Strategy indicating a high level of internal consistency. Table 4 represents the summary of Cronbach Alpha coefficients and inter-observer reliability.

\section{Table 4 Cronbachalpha's and inter-rater reliability of initial instrument}

\begin{tabular}{|ll|}
\hline Construct & $\begin{array}{l}\text { Cronbach } \\
\text { Alpha }\end{array}$ \\
\hline Business & .76 \\
Strategy & \\
IT Strategy & .82 \\
ICT & .71 \\
Dynamics & \\
NOFs & .81 \\
Inter- & .70 \\
observer & $\mathrm{F}=4.945$ \\
reliability & Sig: .000 \\
\hline
\end{tabular}

\subsection{Full Study}

The research is aimed at a broad sample of private and public sector organizations in Australia from seven selected industry groups of the Australian and New Zealand Standard Industrial Classification (ANZSIC). The sectors covered are Government Administration and Defence, Manufacturing, Electricity Gas and Water Supply, Construction, Communication Services, Finance and Insurance, Health and Community Services. These groups have obtained the highest mean overall business value from ICT among 17 groups in the ANZSIC classification ((NOIE), 2005). All Chief Executive Officers (CEOs) were contacted and asked to complete a web-based questionnaire on 
the basis of a five point Likert scale. The use of email and websites allowed us to reach a broad audience (Apigian et al., 2006). Hence, an online questionnaire was located on a web server, and a web link to this server was provided in invitation emails. Stevens (2002) suggested a case-to-variable ratio of 5:1 to guarantee a reliable principal component analysis (PCA) procedure; however, some researchers have worked with ratios as low as 2:1. Therefore, in an effort to achieve an acceptable case-to-variable result, we utilized all 3770 email addresses rented from the Impact List Company. Of the 3770 emails sent to top Australian mangers, 312 were completed and returned, and 682 were returned as incorrect or otherwise invalid and undeliverable addresses. As the emails had an opt-out feature, 206 participants decided not to participate. Hence, the overall response rate for this study was $10.1 \%$. While a higher response rate is desirable in any research endeavour, this response rate is reasonable, given the comprehensiveness and length of the instrument. Moreover, for quantitative analysis, samples in excess of 30 are considered adequate for most exploratory research (Bergeron and Raymond, 1997). Table 5 contains a summary of research data.

Table 5 Summary of data collected

\begin{tabular}{|c|c|c|c|c|c|}
\hline & Frequency & $\begin{array}{l}\text { Percentage } \\
\%\end{array}$ & & Frequency & $\begin{array}{l}\text { Percentage } \\
\%\end{array}$ \\
\hline Job Title & & & & & \\
\hline $\begin{array}{l}\text { Chief Executive } \\
\text { Officer }\end{array}$ & 208 & $67.8 \%$ & $\begin{array}{l}\text { Annual } \\
\text { revenue }\end{array}$ & & \\
\hline $\begin{array}{l}\text { Chief Information } \\
\text { Officer }\end{array}$ & 30 & $9.8 \%$ & $\begin{array}{l}\text { Less than } 10 \\
\text { Million (Aus\$) }\end{array}$ & 117 & $37.9 \%$ \\
\hline Other & 69 & $22.5 \%$ & $\begin{array}{l}\text { Between } 10 \mathrm{M} \\
\text { and } 100 \mathrm{M}\end{array}$ & 88 & $28.5 \%$ \\
\hline Total & 307 & $100 \%$ & $\begin{array}{l}\text { Between } 100 \\
\mathrm{M} \text { and } 500 \mathrm{M}\end{array}$ & 82 & $26.2 \%$ \\
\hline Type of Industry & & & $\begin{array}{l}\text { More than } 500 \\
\text { M }\end{array}$ & 14 & $4.5 \%$ \\
\hline $\begin{array}{l}\text { Communications } \\
\text { Services }\end{array}$ & 29 & $9.39 \%$ & Not Known & 11 & $2.9 \%$ \\
\hline $\begin{array}{l}\text { Electricity, Gas, } \\
\text { and Water Supply }\end{array}$ & 7 & $2.27 \%$ & Total & 312 & $100.0 \%$ \\
\hline Construction & 37 & $11.97 \%$ & & & \\
\hline $\begin{array}{l}\text { Government } \\
\text { Administration }\end{array}$ & 39 & $12.62 \%$ & $\begin{array}{l}\text { Number of } \\
\text { Employees }\end{array}$ & & $58.6 \%$ \\
\hline $\begin{array}{l}\text { Finance and } \\
\text { Insurance }\end{array}$ & 52 & $16.50 \%$ & Less than 999 & 181 & $31.1 \%$ \\
\hline Health and & & & 1000 to 9999 & & \\
\hline Community & 39 & & & 96 & $8.1 \%$ \\
\hline Services & & $12.62 \%$ & & & \\
\hline Manufacturing & 83 & $26.54 \%$ & $\begin{array}{l}10000 \text { to } \\
99999\end{array}$ & 26 & $2.3 \%$ \\
\hline None & 26 & $8.09 \%$ & Not Known & 9 & $100.0 \%$ \\
\hline Total & 312 & $100.00 \%$ & Total & 312 & \\
\hline
\end{tabular}

\subsection{Construct Validity}

To ensure the validity of the constructs used to test the research model, the relationships between the constructs and the items should be examined. Because multi-item variables measure each construct, Principal Component Analysis (PCA) with varimax rotation was employed to test the validity of the instrument. 
Using the iterative sequence of factor analysis, B15, B16, I13, N12, N15 were eliminated from the instrument. The rest of the items are loaded with their hypothesized variables. Hence, the final instrument reduces to 44 items. Appendix B presents the final factor loadings.

\section{RESULTS AND DISCUSSION}

First, the initial reliability of the instrument was tested in order to ensure the soundness of the instrument. The recommended measure of the internal consistency of a set of items is provided by Coefficient alpha which results directly from the assumptions of the domain sampling model (Churchill, 1979). Coefficient alpha and item-scale correlation coefficients were used to identify those items that did not have a common core. The threshold for the cut-off point was quite judgemental (Molla and Licker, 2005), however to ensure that the items were adequate measures of the constructs, a high cut-off value of 0.4 was used. Therefore, items with a correlation coefficient below 0.4 were dropped from the instrument. Therefore, B14, B17, B18 from Business Strategy, I4, I5, I10, I12 from IT strategy, and N11, N13, N16, N17, N18, N19 from NOF constructs were dropped. All remaining correlations with the corrected itemscale ( $r \geq 0.4$ ) were significant at $\rho=0.05$. All Cronbach alphas exceeded 0.80, confirming that the measures were reliable (see Table 6).

\subsection{Testing the Measurement Model}

Convergent validity refers to a situation where items that measure the same factor correlate highly with one another (Litwin, 1995). Two tests were employed to assess convergent validity. The first test is item reliability, which is measured by the factor loading of the item on the construct. The second test of convergent validity is the composite reliability of each construct. There is no generally accepted level of what constitutes an acceptable factor loading analysis (Thonget al., 1996). (Hair, 2010) recommended that a loading should be at least 0.55 which explains at least 30 percent of the variance in the construct. However, many IS researchers have used the 0.50 level (Rivard and Huff, 1988; Amoroso and Cheney, 1991; Thonget al., 1996). (Nunnally and Bernstein, 1994) guideline of 0.80 for assessing reliability coefficients was used to assess composite reliability. Table 6 represents the assessment of the measurement model. The results suggest that the convergent validity of the measurement is adequate. The item-total correlation coefficients of business strategy (0.41 to 0.74), IT strategy (0.40 to 0.76$)$, ICT dynamics (0.65 to 0.85$)$, Management Support (0.70 to 0.78 ), and NOFs (0.40 to 0.85$)$ are also high. Figure 2 represents the final research model.

Discriminant validity is the degree to which items differentiate between constructs, or measure different constructs (Thong et al., 1996). The test used to ensure discriminate validity was to examine whether each item loads more highly on its associated construct than on other constructs (Thompson, 2004). Appendix 2 presents the factor pattern matrix that shows the loadings of each item on all constructs. Except for 4 items (B15, B16, N12, N15 with 0.47, 0.47, 0.15, 0.44 loadings respectively), the rest of the items were greater than 0.50 and loaded more highly on their hypothesized constructs than on any other constructs. 
Regarding the fact that the item N12 is far from the threshold and the closeness of the rest three items, it seems that there is just one item that violates the discriminate validity. The relevant item loadings were statistically significant at 0.05 . Hence, all items, except the above items, passed the test for discriminant validity.

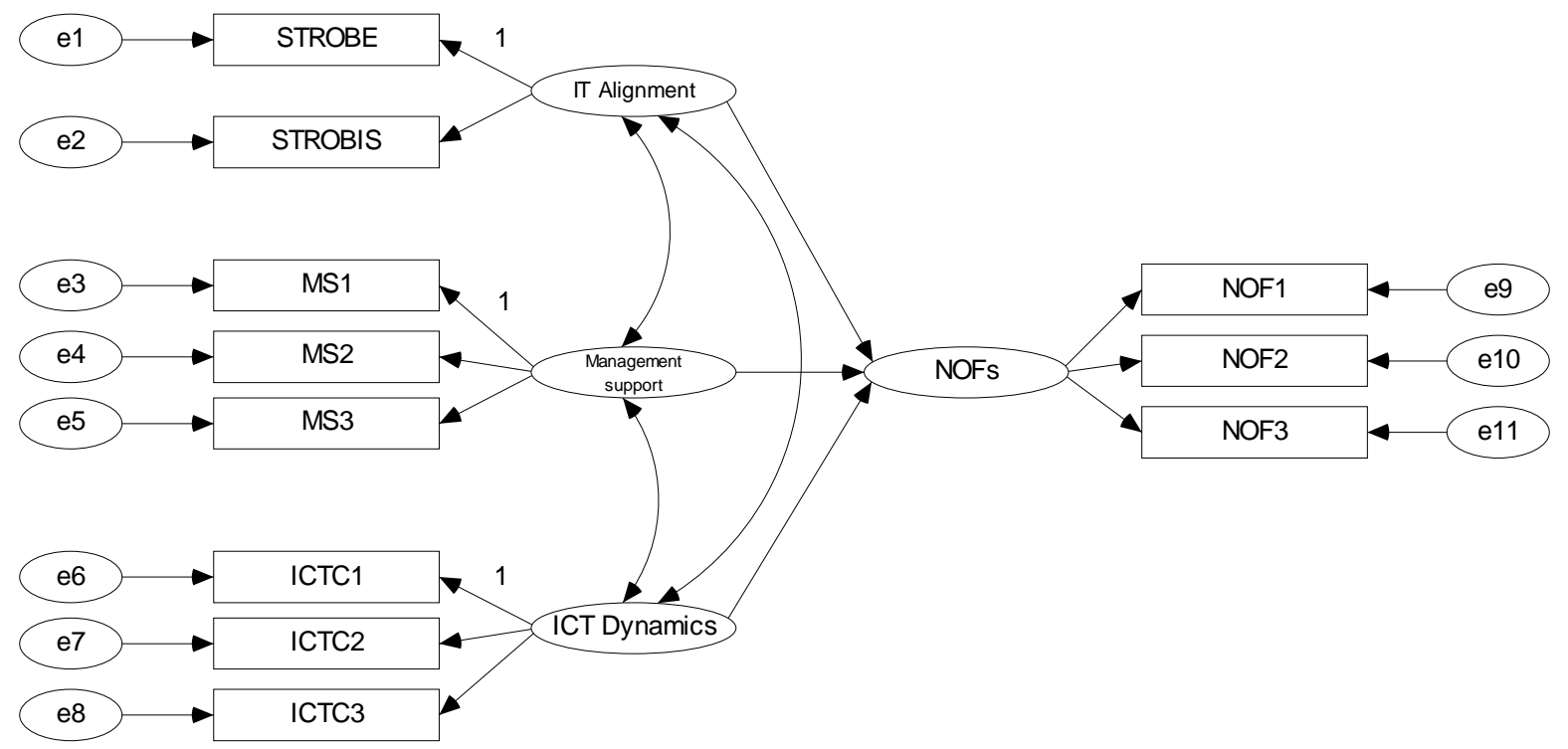

Figure 2 The Proposed Model with the Validated Instrument

\section{CONCLUSION}

Various internal and external variables have contributed to the evolution of new organizational forms. As an influencing variable ICT has been one of the important variables in the transformation process toward new forms of organization. These approaches are discussed around three main areas of context, process and variables. Cumulative results from the previous studies that examined the relationship between ICT and NOFs were plagued with ambiguities and inconsistencies. At the same time, understanding the clear-cut impacts of ICT on organization requires a mechanism in which various domains of ICT, in terms of internal and external are considered. We tried to develop a model to address this gap. It is a working model of ICT- NOF and does not claim to be comprehensive. The business strategy, IT strategy, ICT Dynamics and management support provide meaningful indicators of ICT impacts in the evolution of NOFs. Therefore, both researchers and practitioners can take benefit of the research instrument and model. Researchers can use the model and instrument in future research endeavours. Managers can chart the transformation of their organizations using the common variables identified in this paper and benchmark their organizations against both historical data and industry best practices.

Finally, an important issue that should be considered is that the effect of environmental conditions on the pervasiveness of ICTs impacts was not 
examined in this study as the scope of the study was limited to internal and organisational factors. Particularly the study, although constitutes a cross sectional survey, was limited to Australian organizations. Therefore, the effects of macroeconomic conditions were not investigated. Therefore we suggest to include some influencing external factors and some macroeconomic conditions in relation with ICTs in future research. Another important issue is the lack of appreciation from information intensity of the industry. Some specific industries such as insurance, banking, and finance are more information intensive than other section. Hence the speed and the effectiveness of ICT impact can vary depending on the type of the industry. As this study was conducted as a cross sectional survey of several industries, such effects were not monitored. Longitudinal investigation may further augment the empirical validity and generalizability of the proposed model and research instrument. In general, it is worth noting that including the environmental factors, the type of industry and conducting a longitudinal study can promote the comprehensiveness and generalizability of the proposed model.

\begin{tabular}{|c|c|c|c|c|c|c|c|c|c|}
\hline $\begin{array}{l}\text { Latent } \\
\text { Construct }\end{array}$ & Items & Mean & $\begin{array}{l}\text { Standard } \\
\text { Deviation }\end{array}$ & $\begin{array}{l}\text { Cronbach's } \\
\text { alpha }\end{array}$ & $\begin{array}{l}\text { Latent } \\
\text { Construct }\end{array}$ & Items & Mean & $\begin{array}{l}\text { Standard } \\
\text { Deviation }\end{array}$ & $\begin{array}{l}\text { Cronbach's } \\
\text { alpha }\end{array}$ \\
\hline \multirow{16}{*}{ BUSS } & & & & 0.89 & \multirow{13}{*}{ NOF } & & & & 0.84 \\
\hline & B1 & 72.68 & 40.06 & $0.72^{\alpha}$ & & $\mathrm{N} 1$ & 65.61 & 68.89 & $0.77^{\alpha}$ \\
\hline & B2 & 72.39 & 40.31 & 0.74 & & N2 & 66.36 & 66.35 & 0.77 \\
\hline & B3 & 72.37 & 40.88 & 0.70 & & N3 & 65.58 & 70.30 & 0.67 \\
\hline & B4 & 72.30 & 40.34 & 0.77 & & N4 & 66.33 & 66.95 & 0.70 \\
\hline & B5 & 72.47 & 40.31 & 0.74 & & N5 & 66.36 & 66.04 & 0.79 \\
\hline & B6 & 72.49 & 42.02 & 0.49 & & N6 & 67.23 & 69.96 & 0.65 \\
\hline & B7 & 72.39 & 41.96 & 0.52 & & N7 & 66.41 & 66.35 & 0.78 \\
\hline & B8 & 72.66 & 40.31 & 0.66 & & N8 & 67.20 & 70.70 & 0.59 \\
\hline & B9 & 72.29 & 41.46 & 0.06 & & N9 & 66.43 & 67.74 & 0.69 \\
\hline & B10 & 72.27 & 41.55 & 0.62 & & N10 & 66.43 & 65.44 & 0.85 \\
\hline & B11 & 72.30 & 40.57 & 0.74 & & N14 & 66.53 & 70.07 & 0.52 \\
\hline & B12 & 72.63 & 41.74 & 0.51 & & N15 & 66.51 & 71.39 & 0.40 \\
\hline & B13 & 72.29 & 42.41 & 0.48 & \multirow{7}{*}{ MANS } & & & & \\
\hline & B15 & 72.29 & 42.75 & 0.45 & & & & & 0.88 \\
\hline & B16 & 72.31 & 43.02 & 0.41 & & M1 & 17.40 & 3.94 & $0.71^{\alpha}$ \\
\hline \multirow[t]{14}{*}{ ITS } & & & & 0.87 & & M2 & 17.11 & 4.05 & 0.72 \\
\hline & I1 & 70.96 & 25.83 & $0.76^{\alpha}$ & & M3 & 17.09 & 4.20 & 0.70 \\
\hline & I2 & 70.94 & 26.13 & 0.75 & & M4 & 17.01 & 4.17 & 0.70 \\
\hline & I3 & 70.86 & 26.76 & 0.63 & & M5 & 17.19 & 3.92 & 0.78 \\
\hline & I6 & 70.96 & 27.10 & 0.51 & \multirow[t]{4}{*}{ ICTD } & & & & 0.80 \\
\hline & I7 & 70.95 & 27.83 & 0.46 & & ICT1 & 8.63 & 1.56 & $0.58^{\alpha}$ \\
\hline & I8 & 70.84 & 27.20 & 0.54 & & ICT2 & 8.21 & 1.60 & 0.75 \\
\hline & I9 & 70.86 & 27.94 & 0.44 & & ICT3 & 7.88 & 1.81 & 0.65 \\
\hline & I11 & 70.88 & 27.81 & 0.45 & & & & & \\
\hline & $\mathrm{I} 13$ & 70.71 & 28.28 & 0.40 & & & & & \\
\hline & $\mathrm{I} 14$ & 70.89 & 26.90 & 0.49 & & & & & \\
\hline & $\mathrm{I} 15$ & 70.76 & 27.17 & 0.57 & & & & & \\
\hline & I16 & 70.96 & 27.38 & 0.55 & & & & & \\
\hline & $\mathrm{I} 17$ & 70.74 & 27.85 & 0.46 & & & & & \\
\hline
\end{tabular}

Item- total correlation

Table 6. Summary of measurement model 
ICTs -New Organizational Form linkage in the Australian Context: Theoretical Model and Research Instrument

\section{REFERENCES}

(NOIE), N. O. O. T. I. E. (2005), Achieving Value from ICT: Key Management Strategies on accessed on

Amoroso, D., L. and Cheney, P. H., (1991) "Testing a Causal Model of End user Application Effectiveness," Management Information Systems 8(1), 63-89.

Apigian, C. H., Ragu-Nathan, B. S. and Ragu-Nathan, T. S., (2006) "Strategic profiles and Internet Performance: An empirical investigation into the development of a strategic Internet system," Information \& Management 43(4), 455-468.

Argyres, N. S., (1999) "The Impact of Information Technology on Coordination: Evidence from the B-2 "Stealth" Bomber," Organization Science 10(2), 162-181.

Baker, G., (2002) "The Effects of Synchronous Collaborative Technologies on Decision Making: A Study of Virtual Teams," Information Resources Management Journal 15(4), 78-94.

Bergeron, F. and Raymond, L., (1997) "Managing EDI for corporate advantage: A longitudinal study," Information \& Management 31(6), 319-333.

Beugre, C. D., Acar, W. and Braun, W., (2006) "Transformational leadership in organizations: an environment-induced model.," International Journal of Manpower 27(1), 52-62.

Bowman, E. H., Singh, H., Useem, M. and Bhadury, R., (1999) "When Does Restructuring Improve Economic Performance?," California Management Review 41(2), 33-54.

Brynjolfsson, E. and Hitt, L. M., (2002) "Beyond Computation: Information Technology, Organizational Transformation and Business Performance.," Journal of Economic Perspectives 14(4), 23-48.

Byrd, A., Lewis, B. R. and Bryan, R. W., (2006) "The Leveraging Influence of Strategic Alignment on IT Investment: An empirical examination," Information \& Management 43(3), 308-321.

Byrd, T. A. and Turner, D. E., (2000) "Measuring the Flexibility of Information Technology Infrastructure: Exploratory Analysis of a Construct," Journal of Management Information Systems 17(1), 167-208.

Cairncross, F., (2001) The death of distance: How the communications revolution is changing our lives, Harvard Business School Press, Boston, MA

Chae, B., Yen, H. R. and Sheu, C., (2005) "Information Technology and Supply Chain Collaboration: Moderating Effects of Existing Relationships Between Partners," IEEE Transactions on Engineering Management 52(4), 440-448.

Chan, Y. E., (2002) "Why Haven't we Mastered Alignment?: The Importance of the Informal Organization Structure," MIS Quarterly 1(2), 97-112.

Chan, Y. E., Huff, S. L., Barclay, D. W. and Copeland, D. G., (1997) "Business Strategic Orientation, Information Systems Strategic Orientation, and Strategic Alignment," Information Systems Research 8(2), 125-151. 
Chan, Y. E., Sabherwal, R. and Thatcher, J. B., (2006) "Antecedents and Outcomes of Strategic IS Alignment: An Empirical Investigation," IEEE Transactions On Engineering Management 53(1), 27-47.

Chowdhury, S., (2003) Organization 21C: Someday all Organizations will Lead this Way, Pearson Education, London

Churchill, G. A., (1979) "A Paradigm for Developing Better Measures of Marketing Constructs.," Journal of Marketing Research (JMR) 16(1), 64-73.

Creed, W. E. D. and Miles, R. E., Eds. (1996). Trust in organizations: A conceptual framework linking organizational forms, managerial philosophies and the opportunity costs of control. London, UK, Sage.

Davidow, W. H. and Malone, M. S., (1992) The Virtual Organization, Harper Business, New York

Dewett, T. and Jones, G., (2001) "The role of information technology in the organization: a review, model, and assessment," Journal of Management Information Systems 27(3), 313-346.

Dutton, W. H. (1999). The Virtual Organization: Tele-Access in Business and Industry. in G. Desanctis and J. Fulk (eds.). Shaping organization form, California, Sage Publications.

Finnegan, P. and Longaigh, S. N., (2002) "Examining the effects of information technology on control and coordination relationships: an exploratory study in subsidiaries of pan-national corporations," Journal of Information Technology 17(3), 149-163.

Fulk, J. and Desanctis, G., (1995) "Electronic Communication and Changing Organizational Forms," Organization Science 6(4), 337-349.

Fulk, J. and Desanctis, G. (1999). Articulation of Communication Technology and Organization Form. in G. Desanctis and J. Fulk (eds.). Shaping organization form, California, Sage Publications: 5-31.

Garicano, L., (2000) "Hierarchies and the Organization of Knowledge in Production," Journal of Political Economy 108(5), 874-904.

Ghoshal, S., Bartlett, C. and Moran, P., (1999) "A New Manifesto for Management," Sloan Management Review 15(4), 9-20.

Hair, J. F., (2010) Multivariate data analysis, Pearson Prentice Hall, Upper Saddle River, N.J.

Heckscher, C. (1994). Defining The Post- Bureaucratic Type. in C. Heckscher and A. Donnellon (eds.). The Post- Bureaucratic Organization, Thousand Oaks, CA, Sage: 1462.

Henderson, J. C. and Venkatraman, N., (1999) "Strategic alignment: Leveraging information technology for transforming organizations," IBM Systems Journal 38(2/3), $472-485$.

Heydebrand, W. V., (1989) "New Organizational Forms," Work \& Occupations 16(3), 323-346. 
ICTs -New Organizational Form linkage in the Australian Context: Theoretical Model and Research Instrument

Hill, S., Martin, R. and Harris, M., (2000) "Decentralization, Integration and the PostBureaucratic Organization: the Case Of R\&D," Journal of Maruigenunt Studies 37(4), 563-579.

Hirschheim, R. and Sabherwal, R., (2001) "Detours in the Path toward Strategic Information Systems Alignment," California Management Review 44(1), 87-108.

Holland, C. P. and Geoffrey Lockett, A., (1997) "Mixed Mode Network Structures: The Strategic Use of Electronic Communication by Organizations," Organization Science 8(5), 475-489.

Huber, G., (1993) "How Continental bank Outsourced Its 'Crown Jewels'," Harvard Business Review January/February(121-129.

Hussin, H., King, M. and P., C., (2002) "IT alignment in small firms," European Journal of Information Systems 11(2), 108-127.

Kartseva, V., Gordijn, J. and Tan, Y.-H., (2005) "Toward a Modeling Tool for Designing Control Mechanisms for Network Organizations," International Journal of Electronic Commerce 10(2), 57-84.

Kearns, G. S. and Lederer, A. L., (2003) "A Resource-Based View of Strategic IT Alignment: How Knowledge Sharing Create Competitive Advantage," Decision Sciences 34(1), 1-29.

Kearns, G. S. and Sabherwal, R., (2006) "Strategic Alignment Between Business and Information Technology: A Knowledge-Based View of Behaviours, Outcome, and Consequences.," Journal of Management Information Systems 23(3), 129-162.

Kotorov, R. P., (2001) "Virtual organization: conceptual analysis of the limits of its decentralization," Knowledge and Process Management 8(1), 55-63.

Leavitt, H. H. and Whisler, T. I., (1958) "Management in the 1980's," Harvard Business Review 36(6), 41-48.

Levine, R., Locke, C., Searls, D. and Weinberger, D., (1999) The cluetrain manifesto: The end of business as usual, Perseus Books, New York

Litwin, M. S., (1995) How to Measure Survey Reliability and Validity, SAGE Publications, London

Luftman, J., (1998) "Enablers \& Inhibitors," InformationWeek -(700), 283-286.

Luftman, J. and Kempaiah, R., (2008) "Key Issues for IT Executives 2007," MIS Quarterly Executive 7(2), 99-112.

Luftman, J. N. and Brier, T., (1999) "Achieving and sustaining business-IT alignment," California Management Review 42(1), 109-122.

Maguire, S. and Hardy, C., (2006) "The emergence of new global institutions: A discursive perspective," Organ. Stud. 27(1), 7-29.

Marschak, T., (2004) "Information Technology and the Organization of Firms," Journal of Economics \& Management Strategy 13(3), 473-515.

McNulty, T. and Ferlie, E., (2004) "Process Transformation: Limitations to Radical Organizational Change within Public Service Organizations," Organization Studies 25(1389-1399. 
Miles, R. and Snow, C. C., (2005) Collaborative Entrepreneurship: How Communities of Networked Firms Use Continuous Innovation to Create Economic Wealth, Stanford University Press, Stanford, CA

Molla, A. and Licker, P. S., (2005) "eCommerce adoption in developing countries: a model and instrument," Information \& Management 42(6), 877-899.

Moller, K. and Rajala, A., (1999) "Organizing Marketing in Industrial High-Tech Firms: The Role of Internal Marketing Relationships," Industrial Marketing Management 28(5), 521-535.

Mukherji, A., (2002) "The evolution of information systems: their impact on organizations and structures," Management Decision 40(5/6), 497-507.

Niederman, F. and Brancheu, J. C., (1991) "Information systems management issues for the 1990s," MIS Quarterly Executive 15(4), 475-500.

Nohria, N. and Berkley, J. D. (1994). The Virtual Organization: Bureaucracy, Technology, and the Implosion of Control. in C. Heckscher and A. Donnelon (eds.). The Post-Bureaucratic Organization: New Perspectives on Organizational Change, Thousand Oaks, CA, Sage: 108-128.

Nunnally, J. C. and Bernstein, I. H., (1994) Psychometric Theory, McGraw Hill, New York

Panayides, A., (2004) "Do the Advances in Communications Technology Affect City Size? A Theoretical Investigation.," Journal of Business \& Economic Studies 10(1), 3542.

Pierce, A. C. (2002). The effect of business and information technology strategic alignment on information technology investment returns and corporate performance. The Wayne Huizenga Schooll of Business and Entrepreneurship, Nova Southeastern University.

Piore, M. (1994). Corporate Reform in American Manufacturing and the Challenge to Economic Theory. in T. J. Allen and M. S. Scott Morton (eds.). Information technology and the Corporation of the 1990s, New York, Oxford University: 43-60.

Rajan, R. G. and Wulf, J., (2006) "The Flattening Firm: Evidence from Panel Data on The Changing Nature of Corporate Hierarchies," Review of Economics \& Statistics 88(4), 759-773.

Richardson, H. A., Vandenberg, R. J., Blum, T. C. and Roman, P. M., (2002) "Does Decentralization Make a Difference for the Organization? An Examination of the Boundary Conditions Circumbscribing Decentralized Decision-Making and Organizational Financial Performance," Journal of Management 28(2), 217-244.

Rivard, S. and Huff, S. L., (1988) "Factors of Success for End-user Computing," Communications of the ACM 31(5), 552-561.

Sauer, C. and Willcocks, L., "Strategic Alignment Revisited: Connecting Organizational Architecture and IT Infrastructure," 37th International Conference on System Sciences, Hawaii,

Schilling, M. A. and Steensma, K. H., (2001) "The use of modular organizational forms: an industry-level analysis," Academy of Management Journal 44(1149-1168. 
ICTs -New Organizational Form linkage in the Australian Context: Theoretical Model and Research Instrument

Schreyögg, G. and Sydow, J., (2010) "Organizing for Fluidity? Dilemmas of New Organizational Forms," OrganizationScience 21(6), 1251-1262.

Stevens, J., (2002) Applied multivariate statistics for the social sciences, Lawrence Erlbaum Associates, Mahwah, N.J

Stiroh, K. J., (2002) "Information technology and US productivity revival: What do the industry data say?," Amer. Econom. Rev. 92(5), 1559-1579.

Symon, G., (2000) "Information and communication technologies and the network organization: A critical analysis," Journal of Occupational \& Organizational Psychology 73(4), 389-414.

Tallon, P., Kraemer, K., L. and Gurbaxani, V., (2000) "Executives' Perceptions of the Business Value of Information Technology: A Process-Oriented Approach," Journal of Management Information Systems 16(4), 145-173.

Thompson, B., (2004) Exploratory and Confirmatory factor Analysis, underestanding Concepts and Applications, American psychological Association, Washangton D.C.

Thong, J. Y. L., Yap, C., S. and Raman, K. S., (1996) "Top Management Support, External Expertise and Information Systems Implementation in Small Businesses," Information Systems Research 7(2), 248-267.

Venkatraman, N. (1985). Strategic Orientation of Business Enterprises: The Construct and its Measurement. Pittsburgh, University of Pittsburgh.

Venkatraman, N., (1989) "Strategic Orientation of business Enterprises: the construct, dimensionality, and measurement," Management Science 35(8), 942-962.

Wang, Y. and Tang, T., (2001) "An instrument for measuring customer satisfaction toward web sites that market digital products and services," Journal of Electronic Commerce Research 2(3), 1-16.

White, A., Daniel, E. M. and Mohdzain, M., (2005) "The role of emergent information technologies and systems in enabling supply chain agility," International Journal of Information Management 25(5), 396-410.

Winter, S. and Taylor, S. L. (1999). The Role of Information Technology in the Transformation of Work. in J. FULK and G. DESANCTIS (eds.). Shaping the Organization Form, Thousand Oaks, California, Sage Publications: 101-128.

Workman, M., (2007) "The effects from technology-mediated interaction and openness in virtual team performance measures," Behaviour \& Information Technology 26(5), 355-365. 


\section{Appendix A - The Final Instrument}

\begin{tabular}{|c|c|}
\hline $\begin{array}{c}\text { Item } \\
\text { ID }\end{array}$ & Description \\
\hline B1 & We prefer to cut prices to increase market share. \\
\hline B2 & Our investments are generally aimed at increasing our sale growth rate. \\
\hline B3 & We have attempted to be among the top five firms in our industry. \\
\hline B4 & Our operations can be generally characterized as high risk. \\
\hline B5 & We have a conservative view when making major decisions (rev. scored). \\
\hline B6 & We emphasize effective coordination between different functions (e.g. marketing, manufacturing) \\
\hline B7 & We emphasize the use of planning techniques in our decision-making processes. \\
\hline B8 & In developing business strategy the emphasis would be on cost reduction and using efficiency seeking methods. \\
\hline B9 & We have strong ties with our major customers. \\
\hline B10 & We have strong ties with our major suppliers. \\
\hline B11 & Our philosophy is to defend our present market position prior to expanding into new markets \\
\hline B12 & We seek to use the latest technological innovations. \\
\hline B13 & We pursue the generation of innovative solutions to organizational problems. \\
\hline I 1 & Information Technology (IT) helps the organization to be the top five firms in the industry. \\
\hline I 2 & Information Technology (IT) helps the organization to reach high level of growth rate. \\
\hline I 3 & Information Technology provides the organization with the relevant information to take risk. \\
\hline I 6 & During decision making processes, computer applications are available to managers. \\
\hline I 7 & Information Technology enables the organization to develop detailed analysis of problems \\
\hline I 8 & Information Technology improves overall efficiency of operations in the organization. \\
\hline I 9 & Information Technology enables organization to have strong ties with major customers. \\
\hline I 11 & Information Technology provides innovative solutions in solving our organizational problems. \\
\hline I 14 & Information Technology enables organizations to find new business opportunities. \\
\hline I 15 & Information Technology helps the organization to determine the stages of life cycle for individual operations. \\
\hline I 16 & Information Technology helps us more with long-term rather short-term planning. \\
\hline I 17 & Information Technology provide the firm with the relevant information on different scenarios \\
\hline M1 & Organization management embraces technological initiatives in our organization. \\
\hline M2 & In our competitive environment, corporate success requires special attention to ICT capabilities. \\
\hline M3 & In formulating the organizational strategy we pay special attention to the capabilities provided by ICT. \\
\hline M4 & ICT competencies, such as system reliability, can contribute in achieving the competitive advantages. \\
\hline M5 & ICT capabilities help organizations to enter to new areas of products. \\
\hline ICT1 & ICT capabilities are a contributive factor in promoting inter-organizational cooperation. \\
\hline ICT2 & Our organization makes widespread use of computers. \\
\hline ICT3 & Electronic-based communication is a major form of communication in our organization. \\
\hline N1 & How frequently are the staff asked to participate in hiring or promotion of staff \\
\hline $\mathrm{N} 2$ & How frequently are the staff asked to participate in approval of the budget \\
\hline N3 & How frequently are the staff asked to participate in approval of new policies \\
\hline N4 & How frequently are the staff asked to participate in decisions on critical issues \\
\hline N5 & Management structure is functionally decentralized. \\
\hline N6 & Most decisions made by staff are reviewed by top management. \\
\hline N7 & Division of labour is flexible in our organization. \\
\hline N8 & There is a large number of written rules and policies in our organization \\
\hline N9 & Employees are encouraged to make minor decisions on their own. \\
\hline N10 & A manual containing rules and procedures is available in our organization. \\
\hline N14 & I acquire knowledge of how the business environment is changing by periods of formal education. \\
\hline
\end{tabular}


ICTs -New Organizational Form linkage in the Australian Context: Theoretical Model and Research Instrument

Appendix B: The Final Factor loadings.

\begin{tabular}{|c|c|c|c|c|c|}
\hline Items & $\begin{array}{l}\text { Factor } \\
1\end{array}$ & $\begin{array}{l}\text { Factor } \\
2\end{array}$ & $\begin{array}{l}\text { Factor } \\
3\end{array}$ & $\begin{array}{l}\text { Factor } \\
4\end{array}$ & $\begin{array}{l}\text { Factor } \\
5\end{array}$ \\
\hline B1 & 0.78 & & & & \\
\hline B2 & 0.78 & & & & \\
\hline B3 & 0.76 & & & & \\
\hline B4 & 0.85 & & & & \\
\hline B5 & 0.80 & & & & \\
\hline B6 & 0.55 & & & & \\
\hline B7 & 0.58 & & & & \\
\hline B8 & 0.73 & & & & \\
\hline B9 & 0.69 & & & & \\
\hline B10 & 0.73 & & & & \\
\hline B11 & 0.83 & & & & \\
\hline B12 & 0.58 & & & & \\
\hline B13 & 0.56 & & & & \\
\hline I1 & & 0.79 & & & \\
\hline I2 & & 0.84 & & & \\
\hline I3 & & 0.72 & & & \\
\hline I6 & & 0.58 & & & \\
\hline I7 & & 0.54 & & & \\
\hline I8 & & 0.61 & & & \\
\hline I9 & & 0.51 & & & \\
\hline I11 & & 0.51 & & & \\
\hline I14 & & 0.60 & & & \\
\hline I15 & & 0.67 & & & \\
\hline I16 & & 0.67 & & & \\
\hline I17 & & 0.57 & & & \\
\hline N1 & & & 0.88 & & \\
\hline $\mathrm{N} 2$ & & & 0.86 & & \\
\hline N3 & & & 0.78 & & \\
\hline $\mathrm{N} 4$ & & & 0.82 & & \\
\hline N5 & & & 0.88 & & \\
\hline N6 & & & 0.77 & & \\
\hline N7 & & & 0.87 & & \\
\hline N8 & & & 0.68 & & \\
\hline N9 & & & 0.80 & & \\
\hline N10 & & & 0.94 & & \\
\hline N14 & & & 0.58 & & \\
\hline M1 & & & & 0.80 & \\
\hline M2 & & & & 0.81 & \\
\hline M3 & & & & 0.80 & \\
\hline M4 & & & & 0.81 & \\
\hline M5 & & & & 0.86 & \\
\hline ICT1 & & & & & 0.75 \\
\hline ICT2 & & & & & 0.86 \\
\hline ICT3 & & & & & 0.83 \\
\hline
\end{tabular}




\begin{tabular}{|c|c|c|c|c|c|c|c|c|c|c|c|}
\hline \multicolumn{12}{|c|}{ Appendix C Factor pattern matrix for Discriminant validity } \\
\hline \multirow[t]{2}{*}{ Measure } & \multicolumn{5}{|c|}{ Constructs } & \multirow[t]{2}{*}{ Measure } & \multicolumn{5}{|c|}{ Constructs } \\
\hline & BUSS & ITS & ICTD & MANS & NOF & & BUSS & ITS & ICTD & MANS & NOF \\
\hline B1 & 0.78 & 0.02 & 0.05 & -0.09 & 0.12 & N1 & -0.01 & 0.05 & 0.88 & 0.00 & 0.03 \\
\hline B2 & 0.78 & 0.06 & -0.03 & -0.01 & 0.13 & N2 & 0.02 & 0.02 & 0.86 & 0.00 & 0.06 \\
\hline B3 & 0.76 & 0.03 & 0.06 & 0.00 & 0.01 & N3 & 0.04 & 0.08 & 0.78 & -0.07 & 0.02 \\
\hline B4 & 0.85 & 0.01 & 0.06 & 0.07 & 0.08 & N4 & 0.02 & 0.04 & 0.82 & -0.05 & 0.04 \\
\hline B5 & 0.80 & 0.02 & 0.01 & 0.01 & 0.04 & N5 & 0.02 & 0.02 & 0.88 & -0.01 & 0.03 \\
\hline B6 & 0.55 & 0.14 & 0.06 & -0.04 & 0.15 & N6 & -0.03 & 0.01 & 0.77 & 0.00 & 0.03 \\
\hline B7 & 0.58 & 0.08 & 0.06 & -0.03 & 0.09 & N7 & 0.01 & 0.01 & 0.87 & -0.01 & 0.05 \\
\hline B8 & 0.73 & 0.01 & 0.06 & -0.14 & 0.16 & N8 & -0.03 & 0.04 & 0.68 & 0.01 & 0.02 \\
\hline B9 & 0.69 & 0.00 & 0.12 & 0.06 & 0.14 & N9 & -0.01 & 0.05 & 0.80 & -0.02 & 0.00 \\
\hline B10 & 0.73 & 0.01 & 0.08 & 0.06 & 0.14 & N10 & 0.02 & 0.02 & 0.94 & -0.01 & 0.02 \\
\hline B11 & 0.83 & 0.02 & 0.06 & 0.06 & 0.06 & N12 & 0.10 & 0.01 & 0.15 & 0.06 & 0.11 \\
\hline B12 & 0.58 & 0.05 & 0.00 & -0.08 & 0.01 & N14 & -0.04 & 0.03 & 0.58 & 0.01 & 0.01 \\
\hline B13 & 0.56 & 0.04 & -0.07 & 0.03 & 0.03 & N15 & 0.03 & 0.01 & 0.44 & 0.15 & 0.03 \\
\hline B15 & 0.47 & 0.07 & -0.05 & 0.00 & 0.05 & & & & & & \\
\hline \multirow[t]{2}{*}{ B16 } & 0.47 & 0.15 & -0.02 & -0.03 & 0.02 & M1 & 0.04 & 0.10 & -0.03 & 0.80 & 0.10 \\
\hline & & & & & & M2 & 0.02 & 0.04 & -0.02 & 0.81 & 0.09 \\
\hline I1 & -0.04 & 0.79 & 0.05 & -0.14 & 0.05 & M3 & 0.02 & 0.02 & 0.00 & 0.80 & 0.05 \\
\hline I2 & -0.06 & 0.84 & 0.01 & 0.04 & 0.02 & M4 & -0.01 & 0.02 & -0.01 & 0.81 & 0.03 \\
\hline I3 & 0.06 & 0.72 & 0.00 & -0.07 & 0.01 & M5 & -0.01 & 0.00 & -0.03 & 0.86 & 0.06 \\
\hline I6 & 0.04 & 0.58 & 0.14 & -0.01 & 0.04 & & & & & & \\
\hline I7 & 0.01 & 0.54 & 0.08 & 0.06 & 0.13 & ICT1 & 0.03 & 0.04 & -0.01 & 0.17 & 0.75 \\
\hline I8 & 0.04 & 0.61 & -0.04 & -0.10 & 0.10 & ICT2 & -0.03 & 0.07 & 0.02 & 0.11 & 0.86 \\
\hline I9 & -0.07 & 0.51 & -0.08 & -0.14 & 0.04 & ICT3 & -0.07 & 0.04 & -0.02 & 0.02 & 0.83 \\
\hline I11 & 0.00 & 0.51 & 0.06 & -0.06 & 0.06 & & & & & & \\
\hline I13 & -0.04 & 0.48 & -0.06 & -0.05 & 0.06 & & & & & & \\
\hline I14 & 0.08 & 0.60 & 0.12 & 0.13 & 0.08 & & & & & & \\
\hline I15 & -0.04 & 0.67 & 0.00 & 0.11 & 0.03 & & & & & & \\
\hline I16 & -0.06 & 0.67 & -0.03 & 0.08 & 0.01 & & & & & & \\
\hline I17 & -0.10 & 0.57 & 0.06 & 0.07 & 0.05 & & & & & & \\
\hline
\end{tabular}

